\title{
Intestinal carriage of Campylobacter jejuni and Campylobacter coli among cattle from South-western Norway and comparative genotyping of bovine and human isolates by amplified-fragment length polymorphism
}

\author{
G Johnsen*1,2, K Zimmerman ${ }^{2}$, B-A Lindstedt ${ }^{3}$, T Vardund ${ }^{3}$, H Herikstad $^{2}$ and \\ G Kapperud ${ }^{3,4}$
}

Address: ${ }^{1}$ National Veterinary Institute, Oslo, Norway, ${ }^{2}$ The Norwegian Food Control Authority, Sandnes, Norway, ${ }^{3}$ Norwegian Institute of Public Health, Oslo, Norway and ${ }^{4}$ The Norwegian School of Veterinary Science, Oslo, Norway

Email: G Johnsen* - sarogde@online.no; K Zimmerman - ka_zi@yahoo.com; B-A Lindstedt - bjorn-arne.lindstedt@fhi.no;

T Vardund - traute.vardund@fhi.no; H Herikstad - hallgeir.herikstad@mattilsynet.no; G Kapperud - georg.kapperud@fhi.no

* Corresponding author

Published: 06 June 2006

Acta Veterinaria Scandinavica 2006, I:4 doi:10.1186/175I-0|47-I-4

This article is available from: http://www.actavetscand.com/content///1/4

(c) 2006 Johnsen et al; licensee BioMed Central Ltd.

This is an Open Access article distributed under the terms of the Creative Commons Attribution License (http://creativecommons.org/licenses/by/2.0), which permits unrestricted use, distribution, and reproduction in any medium, provided the original work is properly cited.
Received: 13 May 2006

Accepted: 06 June 2006

\begin{abstract}
In a survey conducted in 1999-200I, the carriage of thermotolerant Campylobacters in cattle was investigated, and the genetic diversity of $C$. jejuni within one herd was examined and compared with human isolates. $C$. jejuni, $C$. coli and other thermotolerant Campylobacter spp. were isolated from intestinal contents from $26 \%, 3 \%$ and $2 \%$ of 804 cattle, respectively. The carriage rate was higher in calves (46\%) than in adults (29\%). Twenty-nine C. jejuni isolates from one herd and $3 \mathrm{I}$ human isolates from the study area were genotyped with amplified-fragment length polymorphism (AFLP). Eighty-three $\%$ of the bovine isolates fell into three distinct clusters with $95-100 \%$ similarity, persistent in the herd for 5-10 months. Among human isolates, $58 \%$ showed $>90 \%$ similarity with bovine isolates. The results show that cattle are a significant and stable reservoir for $C$. jejuni in the study area. Transmission between individuals within the herd may be sufficient to maintain a steady $C$. jejuni population independent of environmental influx. The results of this study have provided new information on $C$. jejuni and $C$. coli transmission, and also on the carriage in cattle, genotypes stability and similarity between bovine and human isolates.
\end{abstract}

\section{Introduction}

During the last 30 years, campylobacteriosis has emerged as an important food-borne bacterial zoonosis causing acute diarrhoea in humans at low infection doses [1-4]. In many developed countries, the disease is currently the most frequently reported bacterial enteric infection in humans $[1,3,4]$. Since the beginning of the 1990 's, a substantial increase has been observed in several countries [3]. In Norway, the incidence of campylobacteriosis dou- bled from 1994 to 1999, according to the Norwegian Surveillance System for Communicable Diseases [5]. Case control studies of sporadic cases, including a recent one from Norway, have identified a number of risk factors $[1,3,6]$. The most frequently reported factors are consumption of poultry meat, contact with animals, including farm animals as cattle, poultry and sheep, drinking undisinfected water, barbequing, and drinking un-pasteurized milk $[1,3,4]$. The sources most frequently incrimi- 
nated in outbreaks of campylobacteriosis are drinking water, un-pasteurized milk and poultry $[1,3,4,7]$.

Thermotolerant Campylobacter spp. are widespread in nature where the principal reservoirs are the alimentary tracts of wild and domesticated mammals and birds $[1,2,7]$. Healthy cattle are a recognized reservoir for Campylobacter. Reported frequencies range from 0.8 to $100 \%$ in faecal material from adult animals $[8,9]$. Although consumption of beef products has rarely been identified as a risk factor, the importance of cattle as a reservoir for human infection is highlighted by the following observations: 1) raw milk as a source in numerous outbreaks, and 2) identification of cattle contacts and raw milk consumption as risk factors in epidemiological studies. However, the relative contribution of these factors to overall disease burden is not known $[2,3,10]$.

Management of cattle in Norway is distinctively different from central parts of Europe, Canada and the United States. The majority of Norwegian cattle belong to one stock, the Norwegian red cattle (NFR). Farms are usually small, housing in average around 30 animals, and raising both dairy and meat cattle, which are fed with the same type of feed. Both slaughtering and calving are evenly distributed throughout the year, and there is no tradition for special fattening calves. The animals spend about eight months indoor, and when they are out, sharing of grazing fields with herds from other farms and frequently shifting of fields are common.

A number of methods have been developed to investigate genetic diversity among Campylobacters in order to trace sources of infection $[11,12]$. The methods differ in their taxonomic range, discriminatory power, reproducibility and ease of interpretation and standardization. Amplified-fragment length polymorphism (AFLP) genotyping is a comparatively rapid method based on PCR and capillary electrophoresis, which combines universal applicability with high discriminatory power [13].

In the present investigation, we assessed the occurrence of C. jejuni and C. coli in cattle from South-western Norway, an area with one of the highest incidence rates of human campylobacteriosis in the country [5]. The aims of the study were to: 1 ) investigate the frequency of $C$. jejuni and C. coli in cattle from the study area, 2) examine the genetic diversity among $C$. jejuni isolates from one of the herds using AFLP, and 3) compare the AFLP profiles of isolates from cattle and human patients from the study area.

\section{Materials and methods Study population and sampling plan}

We examined a total of 804 samples of intestinal contents from cattle representing 333 herds from 16 municipalities in Rogaland County $(\mathrm{n}=764)$ and 8 municipalities in Vest-Agder County $(\mathrm{n}=40)$, South-western Norway. Approximately one-sixth of all cattle produced in Norway originate from this area. The animals were sampled at two abattoirs, which slaughter approximately one third of all cattle in the counties under study. The samplings were performed by the staff at the official meat control. However, there were some deviations in the intended sampling schedule, because the veterinarians responsible for sampling could be absent due to other duties. A pilot study of 88 animals from 74 different herds was conducted during the 6-weeks period from 13 April through 27 May 1999 at the greater of the two abattoirs. One to two days each week, samples from ten animals were collected evenly throughout the day. Since the results of the pilot study showed that the frequency was sufficient to warrant further investigation, we conducted an extended survey at both abattoirs during the 13-months period from January 2000 through January 2001. Each abattoir was visited once a week, and at each visit, samples were taken evenly throughout the day from five to seven animals. A total of 716 animals representing 277 herds were investigated.

\section{Sample collection}

From each animal, approximately 5 grams of intestinal content were collected aseptically from the descending colon immediately after slaughter. Samples were placed in $7.5 \mathrm{ml}$ Cary Blair transport medium (CM0519, Oxoid Ltd., Basingstoke, UK), mixed, and transported in a thermal bag to the laboratory where samples were stored in a refrigerator until cultivation within 24 hours after collection.

\section{Cultivation of samples}

One gram of each sample was transferred to a tube containing $9.0 \mathrm{ml}$ Preston selective enrichment broth consisting of nutrient broth (Oxoid CM0067) supplemented with 5\% lysed horse blood (Oxoid SR0084) and polymyxin $\mathrm{B}$, rifampicin, trimethoprim and cycloheximide (Oxoide SR0117). Tubes were incubated for $24 \mathrm{~h}$ at 42.0 $\pm 0.5^{\circ} \mathrm{C}$ in micro-aerobic atmosphere (CampyGen, CN0025; Oxoid Ltd.). Ten $\mu$ l of each enrichment culture were plated on modified charcoal cefoperazone desoxycholate agar (m-CCDA) with amphotericin B (CM0739 and SR0155; Oxoid Ltd.) and incubated $48 \mathrm{~h}$ at $42.0 \pm$ $0.5^{\circ} \mathrm{C}$ in micro-aerobic atmosphere. From each plate, one colony with characteristic morphology was examined by phase-contrast microscopy. Further confirmation was performed with the 2810 AccuProbe Campylobacter culture identification test kit using the AccuLDR luminometer (Gene-Probe Inc., San Diego, USA), a rapid DNA probe test, which utilizes the technique of nucleic acid hybridization for the identification of thermotolerant Campylobacter spp. Isolates identified as thermotolerant Campylobacter spp. were further tested for hydrolysis of 
hippurate and indoxyl acetate according to standard procedures, which formed the basis for species differentiation [7].

\section{Human clinical isolates}

A total of 31 strains of Campylobacter jejuni isolated from human patients were included in the study. The isolates, sampled by the Department of Medical Microbiology, Stavanger University Hospital during a case control study (Kapperud et al. 2003), included all domestically acquired campylobacteriosis cases in Rogaland County from January throughout June 2000. The isolates were obtained from the strain collection at the Norwegian Institute of Public Health.

\section{AFLP genotyping}

DNA was extracted in a bio robot (EZ-1; Qiagen Instruments AG, Hilden, Germany), according to the manufacturer's instructions. The AFLP analysis was performed as detailed by Lindstedt et al. (2000), using the restriction enzymes BglII and MfeI (New England Biolabs, Beverly, MA, USA). Calculation of similarities between AFLP patterns, cluster analyses, and generation of dendrograms was performed in the computer program GelCompar II (Applied Maths, Kortrijk, Belgium) as described by Lindstedt et al. (2000). Based on knowledge of outbreak strains and the reproducibility of the method designated all strains within a window of similarity of between 95 and $100 \%$ homology as being identical.

\section{Data analysis}

The data were analysed using the statistical package Intercooled Stata for Windows 9.0 (StataCorp LP, Collage Station, Texas, USA). Due to the lack of random sampling, we were reluctant to undertake any advanced statistical analyses. Frequencies with confidence intervals were calculated using the proportion command in Stata, and age groups were compared using the chi-square test.

\section{Results}

\section{Occurrence}

C. jejuni and C. coli were isolated from 208 (26\%, 95\% CI: $23-29 \%)$ and 22 (3\%, 95\% CI: 2-4\%) of 804 cattle examined, respectively. In addition 13 (2\%, 95\% CI: 1-3\%) of the isolates were other thermotolerant Campylobacter spp. not hydrolyzing hippurate and indoxyl acetate, and these were not classified at the species level. In total, thermotolerant Campylobacters were isolated from 30\% (95\% CI: $27-34 \%$ ) of the cattle.

The frequency of thermotolerant Campylobacters among adult cattle $(\mathrm{n}=715)$ and among calves between the age of 1.5 and 9 months $(\mathrm{n}=74)$ were $28.5 \%$ and $46.0 \%$, respectively. Chi squared analyses adjusting for month show that there were significant differences in frequency between the two age groups $(\mathrm{p}=0.0002)$. The frequency of carrier rates in different months ranged from $0 \%$ in January 2000 to $47 \%$ in July 2000 (median, 30\%).

\section{AFLP genotyping}

Of the 333 herds included in the study, five were represented by more than 20 animals and only one (herd $\mathrm{HH}$; $\mathrm{n}=119$ ) with more than 40 animals. Cattle in herd $\mathrm{HH}$ was regarded representative for the area based on management routines, which included uniform breeding and feeding, common grazing fields and frequent trading between herds. AFLP genotyping was used to differentiate 60 C. jejuni isolates, comprising 29 of 32 C. jejuni isolates from herd $\mathrm{HH}$ (three were lost during freeze storage) and 31 clinical isolates obtained from human patients in the study area during 2000. A total of 19 distinct AFLP profiles were detected among the bovine isolates, while the human isolates showed 30 profiles. All isolates grouped within a window of similarity of $80 \%$ (Figure 1 ). The majority of the bovine isolates $(83 \%, \mathrm{n}=24)$ fell into three clusters, each containing eight isolates with 95$100 \%$ similarity (clusters A, B and C in Figure 1). The genetic distance between these three clusters were approximately $85 \%$. All isolates in cluster A were from animals slaughtered in the period July 7 to November 9, while the cluster B isolates were from March 17 to December 1, and cluster C comprised isolates from May 16 to December 27. Hence, the dates of slaughter for the animals from which the strains were isolated overlapped considerably, and there was no clear difference in the seasonal distribution of the clusters. The remaining five bovine isolates were scattered in the dendrogram. Among the human strains, 18 (58\%) showed more than $90 \%$ similarity with one or more bovine isolate. At 95\% similarity, three human isolates fell into cluster B, and two human strains grouped together with the eight bovine isolates in cluster $\mathrm{C}$.

\section{Discussion}

In the present study, we isolated C. jejuni and C. coli from about one-third of healthy cattle from South-western Norway. This is higher than reported from Denmark [14] and Sweden [15], but lower than what is found in the UK and Ireland [9].

The higher carriage rate found in calves than in adult cattle, are supported by results from other studies $[1,9,14,16,17]$. Similar age distributions are also observed among other animals and humans $[3,4,18,19]$. Whether this is due to acquired immunity among adults or more frequent exposure in young individuals is not known $[9,18]$.

We did not find any significant seasonal difference. This would not have been unexpected, since a pronounced summer peak is observed among broiler chickens as well 


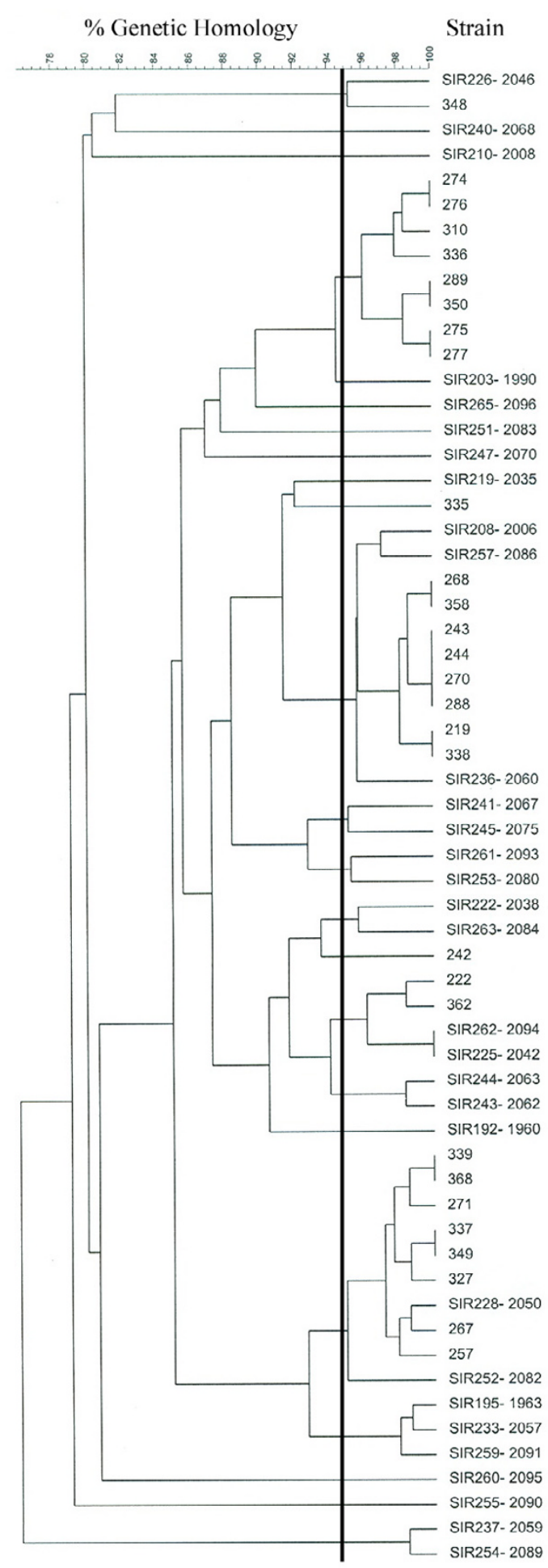

\begin{tabular}{|c|c|c|}
\hline Source & Sample date & Cluster \\
\hline Human & 27.05 .2000 & \\
\hline cattle, adult & 09.11 .2000 & \\
\hline Human & 03.06 .2000 & \\
\hline Human & 15.03 .2000 & \\
\hline cattle, adult & 07.07 .2000 & A \\
\hline cattle, adult & 07.07 .2000 & A \\
\hline cattle, adult & 18.08 .2000 & A \\
\hline cattle, adult & 20.10 .2000 & A \\
\hline cattle, adult & 13.07 .2000 & A \\
\hline cattle, adult & 09.11 .2000 & A \\
\hline cattle, adult & 07.07 .2000 & A \\
\hline cattle, adult & 07.07 .2000 & A \\
\hline Human & 13.03 .2000 & \\
\hline Human & 01.06 .2000 & \\
\hline Human & 22.05 .2000 & \\
\hline Human & 03.06 .2000 & \\
\hline Human & 18.05 .2000 & \\
\hline cattle, adult & 20.10 .2000 & \\
\hline Human & 13.04 .2000 & B \\
\hline Human & 21.06 .2000 & B \\
\hline cattle, adult & 16.06 .2000 & B \\
\hline cattle, adult & 01.12 .2000 & B \\
\hline cattle, adult & 28.04.2000 & B \\
\hline cattle, adult & 28.04 .2000 & B \\
\hline cattle, young & 20.06 .2000 & B \\
\hline cattle, adult & 13.07 .2000 & B \\
\hline cattle, young & 17.03 .2000 & B \\
\hline cattle, adult & 20.10 .2000 & B \\
\hline Human & 01.06 .2000 & B \\
\hline Human & 02.06 .2000 & \\
\hline Human & 11.06 .2000 & \\
\hline Human & 16.06 .2000 & \\
\hline Human & 09.06 .2000 & \\
\hline Human & 19.05 .2000 & \\
\hline Human & 14.06 .2000 & \\
\hline cattle, adult & 28.04 .2000 & \\
\hline cattle, adult & 28.03 .2000 & \\
\hline cattle, adult & 12.12 .2000 & \\
\hline Human & 12.06 .2000 & \\
\hline Human & 15.05 .2000 & \\
\hline Human & 06.05 .2000 & \\
\hline Human & 01.06 .2000 & \\
\hline Human & 15.02 .2000 & \\
\hline cattle, adult & 20.10 .2000 & c \\
\hline cattle, adult & 27.12 .2000 & c \\
\hline cattle, young & 20.06 .2000 & c \\
\hline cattle, adult & 20.10 .2000 & c \\
\hline cattle, adult & 09.11 .2000 & c \\
\hline cattle, adult & 21.09 .2000 & c \\
\hline Human & 27.05 .2000 & c \\
\hline cattle, pre-weaned & 15.06 .2000 & c \\
\hline cattle, adult & 16.05 .2000 & c \\
\hline Human & 18.06 .2000 & c \\
\hline Human & 20.02 .2000 & \\
\hline Human & 02.06 .2000 & \\
\hline Human & 22.06 .2000 & \\
\hline Human & 27.06 .2000 & \\
\hline Human & 24.06 .2000 & \\
\hline Human & 02.06 .2000 & \\
\hline Human & 26.06 .2000 & \\
\hline
\end{tabular}

\section{Figure I}

Dendrogram based on AFLP fragment patterns of 60 Campylobacter jejuni isolates, 29 from intestinal material from one cattle herd and $3 \mathrm{I}$ clinical isolates from human patients in the study area during the study period, with strain identity, source of isolation, isolation date and AFLP profile identity. The vertical line marks $95 \%$ similarity. 
as in humans in Norway $[5,20]$. This indicates that cattle herds are able to maintain a stable Campylobacter population by transmission within the herd. AFLP genotyping of isolates from one of the herds indicates that three distinct C. jejuni clones, each with $95-100 \%$ internal similarity, were present through 5-10 months of the study period. Transmission between individuals within the herd is probably sufficient to maintain a steady population of $C$. jejuni without environmental influx. The duration of colonization in individual animals was not determined in our study, but previous investigations have shown that cattle may shed large quantities of Campylobacters for up to 112 days [8].

Our finding that some of the human clinical isolates from the study area showed close genetic similarity with bovine strains should be interpreted with caution. Direct transmission from cattle to humans cannot be completely excluded, though it is more likely that both species were infected from a common source, most notably through water. Water may constitute the common reservoir linking infections in humans and animals [3]. Recent results indicating a symbiotic relation between Campylobacter and aquatic amoebae may support this hypothesis [21]. Drinking un-disinfected water was the leading risk factor for human campylobacteriosis in a Norwegian case-control study [6], occupational exposure to cattle and other farm animals was also identified as an independent risk, but beef consumption was not. Consumption of un-pasteurized milk is uncommon in Norway, though a few outbreaks related to raw milk has been reported $[22,23]$.

The study contributed with less information than expected because of deviations in the intended sampling schedule. The culturing methods used in this study select for thermo-tolerant Campylobacter species [24]. This may be the reason why mainly $C$. jejuni was isolated. Selective enrichment was used for all samples and may contribute to skewed data. It must also be taken into consideration that only a finite number of colonies were isolated and typed, a limitation allowing the most predominant clones to be isolated. The cattle isolates included in the AFLP typing originated from only one herd, including all Campylobacter isolated from this herd. Due to this limitation, it is difficult to imply associations between human and cattle isolates in general.

\section{Conclusion}

The results show that cattle are a significant and stable reservoir for C. jejuni in the study area. In one of the herds, three distinct genetic clones were present over several months. The genetic similarity between human and bovine isolates may reflect infection from a common source. The highest carriage rates were found among calves versus adults.

\section{Sammendrag}

Forekomst av Campylobacter jejuni og Campylobacter coli $i$ tarm fra storfe fra sørvest Norge og genotypisk sammenligning av bovine og humane isolat ved metoden AFLP

Forekomst av termotolerante Campylobacter spp. hos storfe ble undersøkt i en kartlegging utført i 1999-2001, og den genetiske diversiteten hos $C$. jejuni innen en besetning ble undersøkt og sammenlignet med humane isolat. C. jejuni, C. coli og andre termotolerante Campylobacter spp. ble isolert fra tarminnhold hos henholdsvis $26 \%, 3 \%$ og $2 \%$ av 804 storfe. Frekvensen var større hos kalver (46\%) enn hos voksne dyr (29\%). Tjueni C. jejuni-isolat fra en besetning og 31 humane isolat fra samme område ble karakterisert ved den genetiske fingeravtrykksmetoden AFLP. Av storfeisolatene havnet $83 \%$ i tre distinkte grupper med 95-100\% likhet, vedvarende i besetningen i 5-10 måneder. Av de humane isolatene var 58\% mer enn 90\% lik storfeisolatene. Resultatene viser at storfe er et betydelig og stabilt reservoar for $C$. jejuni i området. Overføring mellom individer innen en besetning ser ut til å være tilstrekkelig til å opprettholde en stabil C. jejuni-populasjon uavhengig av tilførsel fra omgivelsene. Resultatene har gitt informasjon om smitteveier for $C$. jejuni og C. coli med økt kunnskap om nivå hos storfe, stabiliteten til genotypene og likhet mellom humanisolat og storfeisolat.

\section{Acknowledgements}

Thanks to Eystein Skjerve at the Norwegian School for Veterinary Science for helpful assistance with the statistical analysis.

\section{References}

I. Altekruse SF, Stern NJ, Fields PI, Swerdlow DL: Campylobacter jejuni - an emerging foodborne pathogen. Emerg Infect Dis 1999, 5:28-35 [http://PM:10081669].

2. Blaser MJ, Taylor DN, Feldman RA: Epidemiology of Campylobacter jejuni infections. Epidemiol Rev 1983, 5:157-176.

3. Friedman CR, Neimann J, Wegener HC, Tauxe RV: Epidemiology of Campylobacter jejuni infections in the United States and other industrialized nations. In Campylobacter Volume 6. 2.th edition. Edited by: Nachamkin I and Blaser MJ. Washington, D.C., American Society for Microbiology; 2000:121-138.

4. Frost JA: Current epidemiological issues in human campylobacteriosis. Symp Ser Soc Appl Microbiol 200 I:85S-95S.

5. Nygård K, Kapperud G: Campylobacteriosis in Norway 2004 [In Norwegian]. In Commun Dis Rep, Norwegian Inst Public Health, Norway Volume 33. Oslo, Norway; 2005:I-I.

6. Kapperud G, Espeland G, Wahl E, Walde A, Herikstad H, Gustavsen S, Tveit I, Natås O, Bevanger L, Digranes A: Factors associated with increased and decreased risk of Campylobacter infection: a prospective case-control study in Norway. Am J Epidemiol 2003, 158:234-242 [http://PM:I 2882945].

7. Stern NJ, Kazmi SU: Campylobacter jejuni. In Foodborne Bacterial Pathogens Volume 3. Ist ed. edition. Edited by: Doyle MP. New York and Basel, Marcel Dekker, Inc.; 1989:7I-II0.

8. Inglis GD, Kalischuk LD, Busz HW: Chronic shedding of Campylobacter species in beef cattle. J Appl Microbiol 2004, 97:410-420.

9. Stanley K, Jones K: Cattle and sheep farms as reservoirs of Campylobacter. J Appl Microbiol 2003, 94:104S-II3S [http:// PM:I2675942].

10. Potter ME, Kaufmann AF, Blake PA, Feldman RA: Unpasteurized milk. The hazards of a health fetish. J Am Med Assoc 1984, 252:2048-2052. 
II. Nielsen EM, Engberg J, Fussing V, Petersen L, Brogren CH, On SLW: Evaluation of phenotypic and genotypic methods for subtyping Campylobacter jejuni isolates from humans, poultry, and cattle. J Clin Microbiol 2000, 38:3800-38I0 [http://PM:I I0 I5406].

12. Wassenaar TM, Newell DG: Genotyping of Campylobacter spp. Appl Environ Microbiol 2000, 66: I-9 [http://PM:10618195].

13. Lindstedt BA, Heir E, Vardund T, Melby KK, Kapperud G: Comparative fingerprinting analysis of Campylobacter jejuni subsp. jejuni strains by amplified-fragment length polymorphism genotyping. J Clin Microbiol 2000, 38:3379-3387 [http:// PM: 10970387]

14. Nielsen EM: Occurrence and strain diversity of thermophilic Campylobacters in cattle of different age groups in dairy herds. Lett Appl Microbiol 2002, 35:85-89 [http://PM:I208I556].

15. Blixt Y, Borch E, Brandstrom B, Olsson Engvall E: Prevalence and genetic subtyping of thermophilic Campylobacter spp. in Swedish cattle. Int J Med Microbiol 200I, 29I Suppl 31:34-35.

16. Giacoboni GI, Itoh K, Hirayama K, Takahashi E, Mitsuoka T: Comparison of fecal Campylobacter in calves and cattle of different ages and areas in Japan. J Vet Med Sci 1993, 55:555-559 [http:/ /PM:8399732]

17. Grau FH: Campylobacter jejuni and Campylobacter hyointestinalis in the intestinal-tract and on the carcasses of calves and cattle. J Food Prot 1988, 51:857-861 [http:// ISI:A1 988R227400005].

18. Newell DG, Fearnley C: Sources of Campylobacter colonization in broiler chickens. Appl Environ Microbiol 2003, 69:4343-435 I [http://PM:I29022|4].

19. Stanley KN, Wallace JS, Currie JE, Diggle PJ, Jones K: Seasonal variation of thermophilic Campylobacters in lambs at slaughter. J Appl Microbiol 1998, 84: I III-III6.

20. Hofshagen $M$, Kruse $H$ : Reduction in flock prevalence of Campylobacter spp. in broilers in Norway after implementation of an action plan. J Food Prot 2005, 68:2220-2223 [http:// PM: 16245734].

21. Axelsson-Olsson D, Waldenström J, Broman T, Olsen B, Holmberg M: Protozoan Acanthamoeba polyphaga as a potential reservoir for Campylobacter jejuni. Appl Environ Microbiol 2005, 71:987-992.

22. Aasland B: Outbreak of campylobacteriosis after consumption of unpasteurized milk [In Norwegian]. In Communicable Disease Report, Norwegian Institute of Public Health, Norway Volume 26. Oslo, Norway; 1998

23. Wahl $\mathrm{E}$ : Campylobacteriosis after consumption of unpasteurized milk [In Norwegian]. In Commun Dis Rep, Norwegian Inst Public Health, Norway Volume 27. Oslo, Norway; 1999.

24. Corry JEL, Post DE, Colin P, Laisney MJ: Culture media for the isolation of Campylobacters. Int J Food Microbiol I995, 26:43-76.

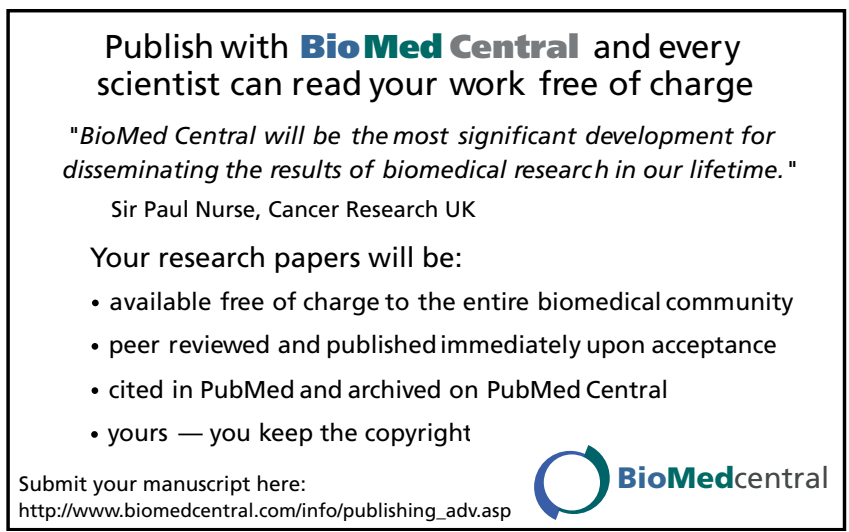

